\title{
SISTEM INSENTIF JASA LINGKUNGAN DI HUT AN LARANGAN ADAT RUMBIO KABUPATEN KAMPAR, RIAU
}

\author{
Enny Insusanty, Emy Sadjati \\ Staff Pengajar Fakutas Kehutanan Universitas Lancang Kuning \\ JIn. Yos Sudarso Km. 8 Rumbai Pekanbaru Riau \\ Email: annovisa@yahoo.com,emy_mnhnilak@yahoo.co.id
}

\begin{abstract}
The Indigenous Prohibited Forestof Rumbio provide benefits for the community in the form of non-timber forest products and environmental services in the form of water resources, but amid the increasing demand for land and economic demands put pressure on forests that threaten forest sustainability. Therefore, this study examines the factors that influence the participation of surrounding communities in conservation and environmental management activities and environmental services incentive system that can be adopted in the Indigenous Prohibited Forestof Rumbio. The method used in this research is survey method with questionnaire and in-depth interviews. Data analysis is descriptive using AHP method and multiple linear regression. This study result in that developed incentive programs for people around The Indigenous Prohibited Forest of Rumbio in the framework of forest conservation are employment (24.17\%), subsidy in second rank (20.15\%) and improvement of conservation techniques in third rank (18.90\%). Factors that significantly influence the participation of respondents are education, knowedge, level of dependence on forests, customary institutions. Incentives are directed to the payment of environmental services by granting rights in the management of environmental services such as water use, non-timber forest product development, and tourism and education activities involving the community.
\end{abstract}

Keywords: system, incentives, environmental services, participation, preference

\section{PENDAHULUAN}

Kawasan Hutan Larangan Adat Rumbio merupakan hutan lindung yang berada di Kabupaten Kampar, Riau seluas $530 \mathrm{Ha}$ yang sampai saat ini masih dipertahankan sebagai hutan lindung adat sesuai dengan aturan adat istiadat lokal dengan tidak mengambil hasil hutan kayu. Hal ini dimungkinkan karena masih kuatnya masyarakat adat dengan kearifan lokalnya untuk tetap mempertahankan kawasan ini ditengah kebutuhan lahan yang semakin tinggi untuk kegiatan pertanian dan perkebunan.

Walaupun sebagai Hutan

Larangan Adat Rumbio, tidak serta merta membuat sumberdaya yang ada dalam kawasan tidak dapat dimanfaatkan oleh anak kemenakan Kenagarian. Pemanfaatan hasil hutan dilakukan dengan cara mencari bibit, 
memanen buah, mengambil getah, berburu. Bibit yang banyak dicari adalah meranti, buah cempedak hutan. Terdapat enam kawasan Ghimbo di Hutan Larangan Adat yang memiliki pemanfaatan yang berbeda. Kawasan Ghimbo Potai saat ini hanya dimanfaatkan untuk mengambil buah, getah dan bibit serta lokasi penelitian. Sedangkan lima kawasan lain selain dapat memanfaatkan seperti Ghimbo Potai dapat juga dimanfaatkan untuk mengambil kayu bakar dari pohon yang tumbang dan dari ranting pohon.

Selain hasil hutan tangible terdapat potensi jasa lingkungan yang bersifat intangible berupa sumberdaya air yang bersumber dari mata air dari Hutan Larangan Adat Rumbio. Salah satu sumber air yang paling besar berlokasi di Bukit Sikumbang yang telah dimanfaatkan sejak tahun 2005. Pemanfaatan air ini untuk kepentingan masyarakat setempat dalam memenuhi kebutuhan air minum dan juga telah diperjual belikan ke luar daerah yang sudah pendistribusiannya sampai ke wilayah Bangkinang ibu kota Kabupaten Kampar dan daerah lain seperti ke Perawang di Kabupaten Siak dan Pangkalan Kerinci di Kabupaten Pelalawan. Penelitian yang dilakukan oleh Insusanty dan Ratnaningsih (2014) menunjukkan bahwa nilai ekonomi air untuk keperluan rumah tangga masyarakat sekitar Hutan Larangan Adat Rumbio sebesar Rp 347.871.206 per tahun dan potensi jasa lingkungan penyerapan karbon hutan adat yaitu 143,55 ton/ha. Air yang dihasilkan hutan adat juga telah dijual kepada pembeli oleh beberapa pengusaha air yang merupakan masyakat lokal dengan pola yang masih sederhana dengan menggunakan gerigen 30 liter dan galon air 19 liter.

Dalam pengelolaan Hutan Larangan Adat Rumbio lembaga adat berperan untuk mengatur hutan adat sedangkan untuk jasa air diatur oleh desa melalui kelompok usaha penjualan air. Selain itu juga terdapat Yayasan Pelopor berperan aktif untuk melaksanakan berbagai kegiatan di Hutan Larangan Adat dan terdapat pula Penyuluh Kehutanan Swadaya yang diberdayakan oleh desa. Penyuluh tersebut dengan diberikan pelatihan sebagai penyuluh oleh Dinas Kehutanan Kabupaten Kampar. Instansi pemerintah Kabupaten Kampar memiliki perhatian dalam upaya pelestarian kawasan melalui instansi teknis seperti Dinas Kehutanan dan Badan Lingkungan 
Hidup. Untuk kegiatan perencanaan Hutan Larangan Adat telah dibuat Master Plan Hutan Larangan Adat Rumbio oleh Bappeda Kabupaten Kampar (Insusanty dan Sadjati, 2015)

Partisipasi masyarakat untuk menjaga kelestarian hutan adat merupakan hal pokok yang perlu diperhatikan untuk menjaga kelestarian hutan. Sebagai kawasan hutan lindung adat, Hutan Larangan Adat Rumbio memiliki banyak manfaat baik tangible maupun intangible, yang apabila dimoneterkan merupakan nilai ekonomi yang sangat tinggi. Manfaat tangible merupakan manfaat berwujud, seperti hasil hutan kayu dan non kayu. Adapun manfaat intangible merupakan manfaat tidak berwujud yang kebanyakan berupa jasa lingkungan seperti diantaranya habitat satwa, tata air, serap karbon, dan wisata alam. Kesemua manfaat tersebut hanya bisa ada jika lingkungan/ekosistem terjaga, sehingga disebut sebagai jasa lingkungan atau ecosystem services (Ekayani et al. 2014a)

Pembayaran jasa lingkungan (PJL) merupakan skema yang bertujuan untuk merestorasi dan melindungi ketersediaan barang dan jasa lingkungan yang berkelanjutan (Idrus et al. 2016). Menurut Ekayani et al. (2014b) penerapan pembayaran jasa lingkungan dapat mengeliminir kerusakan hutan akibat perambahan hutan yang dilakukan oleh masyarakat. Selain itu, PJL juga dapat menjembatani antara kepentingan ekonomi maupun ekologi (Ekayani et al. 2014a; Vibrianto et al. 2015). Oleh karena itu, inisiasi pembayaran jasa lingkungan untuk kelestarian ekosistem Hutan Larangan Adat Rumbio di Kabupaten Kampar merupakan salah satu bentuk insentif yang dapat diberikan kepada masyarkat yang telah berkontribusi untuk menjaga kelestarian hutan. Adanya insentif merupakan salah satu upaya yang dapat dilakukan untuk mendorong dan mendukung masyarakat dalam pengelolaan lingkungan dan berpartisipasi aktif dalam menjaga kelestarian hutan. Model insentif yang ingin diperoleh sesuai dengan keinginan dan kebutuhan masyarakat. Preferensi masyarakat menjadi salah satu tolok ukur keberhasilan dan menunjukkan tingkat partisipasi masyarakat dalam kegiatan pelestarian pengelolaan lingkungan.

Keberadaan Hutan Larangan Adat Rumbio selama ini telah memberikan manfaat bagi masyarakat, namun 
ditengah kebutuhan lahan dan tuntutan ekonomi yang semakin besar memberikan tekanan kepada hutan seperti illegal loging, pengambilan hasil hutan berlebihan dan pengalihan fungsi lahan sedikit demi sedikit dengan menggeser batas kawasan hutan yang oleh masyarakat setempat disebut "naik ujung". Walupun kegiatan ini dapat diatasi oleh masyarakat setempat namun dapat mengancam kelestarian hutan dimasa yang akan datang. Oleh sebab itu perlu diketahui faktor yang mempengaruhi partisipasi masyarakat pada kegiatan pelestarian dan pengelolaan lingkungan. Kelestarian hutan perlu didukung oleh pemerintah dengan memberikan insentif yang tepat di desa-desa sekitar kawasan Hutan Larangan Adat Rumbio sesuai dengan preferensi dan kebutuhan masyarakat sehingga dapat meningkatkan kesejahteraan masyarakat dan kelestarian hutan adat dapat terjaga.

\section{METODE PENELITIAN}

\section{Tempat dan Waktu}

Penelitian ini dilaksanakan selama 8 (delapan) bulan, dimulai pada bulan Maret sampai dengan bulan September 2016 yang meliputi kegiatan persiapan, penelitian lapangan, pengolahan data dan penyusunan laporan. Adapun pemilihan lokasi penelitian ditentukan secara purposive sampling yaitu di Hutan Larangan Adat Rumbio dan masyarakat yang berada di sekitar hutan adat tersebut. Hutan Larangan Adat Rumbio merupakan salah satu hutan adat yang ada di Propinsi Riau yang telah dikelola dan memanfaatkan jasa lingkungan secara komersil yaitu usaha penjualan air dan memiliki potensi Hasil Hutan Bukan Kayu (HHBK), wisata dan pendidikan.

\section{Alat dan Bahan Penelitian}

Bahan yang digunakan pada penelitian ini adalah kuisioner yang merupakan kumpulan pertanyaan yang diajukan. Sedangkan alat yang digunakan berupa alat-alat tulis, komputer, software Minitab dan kamera.

\section{Jenis Data dan Metode Pengumpulan Data}

Jenis data yang dikumpulkan dalam penelitian ini terdiri dari data primer dan data sekunder. Data-data yang diperlukan diperoleh melalui studi pustaka (desk study) dan wawancara mendalam dengan stakeholders terkait pengelolaan Hutan Larangan Adat Rumbio yang terdiri dari masyarakat 
sekitar hutan, instansi pemerintah, dan LSM Pelopor.

Untuk memperoleh data digunakan teknik pengumpulan data meliputi pengamatan langsung, kuisioner, wawancara mendalam, dan diskusi kelompok terfokus (FGD). Pengamatan langsung terhadap aktivitas masyarakat dalam pemanfaatan jasa lingkungan air diamati secara langsung untuk mendapat gambaran nyata tentang pola tersebut.

Pengumpulan data primer di lapangan dilakukan dengan teknik wawancara mendalam (dept interview) dengan menggunakan kuisioner dan daftar pertanyaan yang dilakukan pada tokoh-tokoh kunci (key informan) dengan metode snowball sampling maupun pihak-pihak lain yang terkait langsung dengan pengelolaan hutan adat. Tokoh-tokoh tersebut baik yang ada di antara lain dari unsur pemerintahan Kepala Desa, pemuka masyarakat, Dinas Kehutanan.

Metode yang digunakan dalam pengambilan data pada penelitian ini adalah purposive sampling dengan kriteria memiliki tingkat ketergantungan yang tinggi terhadap hutan. Jumlah responden adalah 75 orang yang tersebar pada 4 desa di sekitar Hutan
Larangan Adat Rumbio. Dengan jumlah penduduk (KK) di setiap desa tidak sama, perlu dilakukan alokasi jumlah responden untuk setiap desa agar proporsional terhadap jumlah penduduk (KK) desa yang diwakilinya. Jumlah responden masing-masing desa dialokasikan berdasarkan rasio jumlah rumah tangga di setiap desa dengan sampel dipilih secara acak disajikan pada Tabel 1.

\begin{tabular}{|c|c|c|c|c|c|}
\hline & $\begin{array}{c}\text { Desa } \\
\text { Koto } \\
\text { Tibun }\end{array}$ & $\begin{array}{l}\text { Desa } \\
\text { Padang } \\
\text { Mutung }\end{array}$ & $\begin{array}{c}\text { Desa } \\
\text { Rumbio }\end{array}$ & $\begin{array}{l}\text { Desa } \\
\text { Pulau } \\
\text { Sarak }\end{array}$ & Total \\
\hline $\begin{array}{l}\text { Jumlah KK } \\
\text { Rasio } \\
\text { alokasi }\end{array}$ & $\begin{array}{l}450 \\
4 \%\end{array}$ & $\begin{array}{l}550 \\
4 \%\end{array}$ & $\begin{array}{l}526 \\
4 \%\end{array}$ & $\begin{array}{l}340 \\
4 \%\end{array}$ & $\begin{array}{c}1866 \\
4 \%\end{array}$ \\
\hline $\begin{array}{l}\text { Jumlah } \\
\text { responden }\end{array}$ & 18 & 22 & 21 & 14 & 75 \\
\hline
\end{tabular}

\section{Analisa Data}

Data-data yang diperoleh dianalisis secara deskripsi kuantitatif untuk mengetahui tingkat partisipasi masyarakat pengelolaan jasa lingkungan dengan memberi skor 3 pada pilihan jawaban a, 2 pada pilihan jawaban b, dan 1 pada pilihan jawaban c. Menurut Yitnosumarto (2000) dalam menentukan nilai tinggi, sedang, atau rendah dalam pengelolaan jasa lingkungan digunakan interval yang diformulasikan sebagai berikut: 
$I=\frac{N T-N R}{K}$

dimana NT adalah nilai tertinggi, NR adalah nilai terendah, dan $\mathrm{K}$ adalah kategori.

Untuk mengidentifikasi faktorfaktor yang mempengaruhi partisipasi masyarakat desa pada kegiatan pelestarian dan pengelolaan lingkungan, digunakan analisis regresi linier berganda dan deskriptif kualitatif dengan bantuan peringkatan jawaban responden menggunakan skala likert.

$$
\begin{aligned}
& Y=a+b_{1} X_{1}+b_{2} X_{2}+\ldots+b_{n} X_{n} \\
& Y=\text { partisipasi } \\
& a=\text { konstansta } \\
& X_{1} \ldots n=\text { faktor sosial ekonomi }
\end{aligned}
$$

Sedangkan untuk pengambilan keputusan terhadap program insentif yang tepat pada kegiatan jasa ligkungan di Hutan Larangan Adat Rumbio dilakukan dengan metode AHP (Analytic Hierarchy Process) .

Metode AHP dikembangkan oleh Thomas Saaty pada 1970-an. Metode ini merupakan salah satu teknik yang telah mendapat pengakuan luas dalam sejumlah disiplin ilmu, terutama ketika mencari solusi terhadap masalah yang dihadapi dengan teknik merangking keputusan sesuai preferensi dari masyarakat. Dalam survei ini, AHP akan dilakukan untuk menilai preferensi masyarakat lokal pada program insentif yang diberikan. Setiap program insentif akan dibandingkan satu banding satu, dan jumlah rata-rata dari masing-masing pasangan dievaluasi untuk mengetahui program insentif, yang paling disukai oleh masyarakat setempat.

\section{HASIL DAN PEMBAHASAN \\ Karakteritik Responden}

Responden yang dipilih dalam penelitian ini berjumlah 75 responden yang terbagi pada 4 Desa yaitu Desa Padang Mutung, Rumbio, Koto Tibun dan Pulau Sarak yang dilakukan secara acak. Di bawah ini akan dipaparkan karakteristik responden secara umum menurut umur, tingkat pendidikan, jumlah anggota keluarga, suku dan

\begin{tabular}{|c|c|c|c|c|}
\hline$\overline{\mathbf{N}}$ & \multicolumn{2}{|c|}{ Uraian } & $\mathbf{N}$ & $\%$ \\
\hline \multirow{5}{*}{1.} & \multirow{5}{*}{ Umur (tahun) } & $21-30$ & 15 & $20,00 \%$ \\
\hline & & $31-40$ & 18 & $24,00 \%$ \\
\hline & & $41-50$ & 24 & $32,00 \%$ \\
\hline & & $51-60$ & 16 & $21,33 \%$ \\
\hline & & $>60$ & 2 & $2,67 \%$ \\
\hline \multirow{5}{*}{2.} & \multirow{5}{*}{$\begin{array}{l}\text { Pendidikan } \\
\text { Formal }\end{array}$} & $\begin{array}{l}\text { Tidak } \\
\text { ada data }\end{array}$ & 2 & $2,67 \%$ \\
\hline & & SD & 12 & $16,00 \%$ \\
\hline & & SMP & 26 & $34,67 \%$ \\
\hline & & SMA & 25 & $33,33 \%$ \\
\hline & & S1 & 10 & $13,33 \%$ \\
\hline \multirow{2}{*}{3.} & \multirow{2}{*}{ Suku } & $\begin{array}{l}\text { Tidak } \\
\text { ada data }\end{array}$ & 2 & $2,67 \%$ \\
\hline & & Batak & 1 & $1,33 \%$ \\
\hline
\end{tabular}
pendapatan per bulan seperti disajikan pada tabel 2.

\section{Tabel 2. Karakteristik Responden}




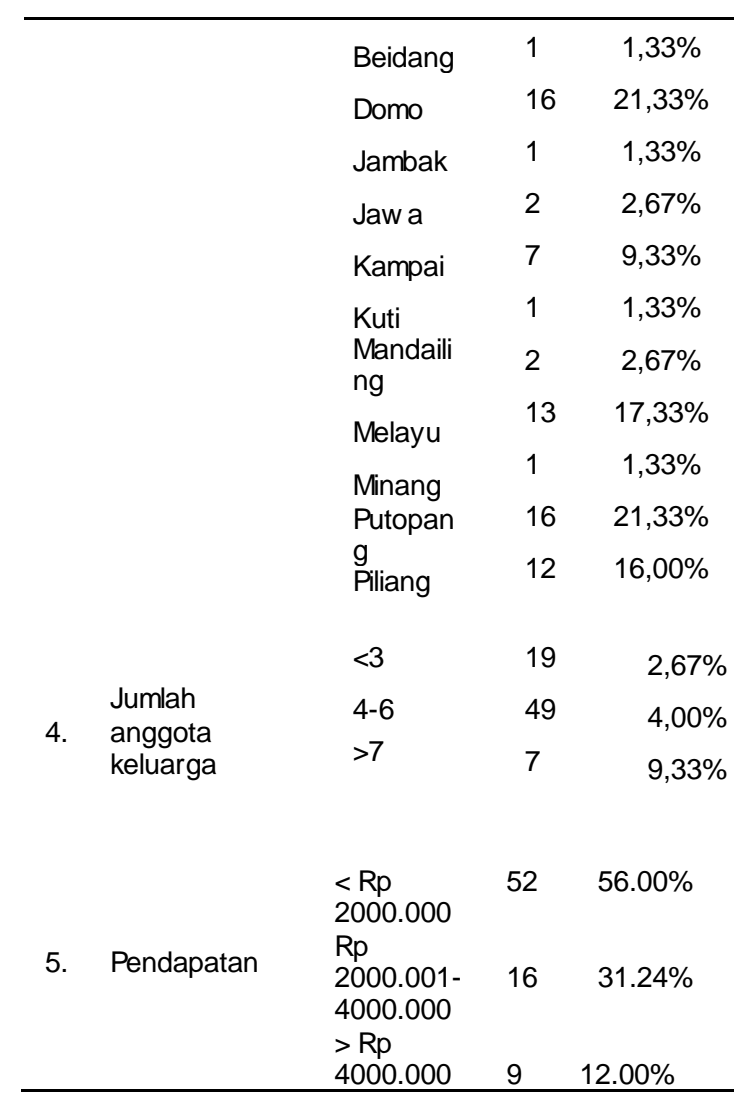

Dari hasil tersebut

memperlihatkan umur responden paling banyak berada pada usia 41-50 tahun sebesar $32 \%$ yang tinggal didesa dan mencari nafkah dari berbagai sumber mata pencaharian di desa. Jika dilihat kelompok tingkat pendidikan paling banyak adalah pada tingkat rendah yaitu SD dan SLTP yaitu 38 orang (50,67\%), sedangkan tingkat pendidikan SMA pada posisi sedang sebanyak 25 orang $(33,33 \%)$. Responden yang memiliki pendidikan di perguruan tinggi sebanyak 10 orang (13,33\%). Hal ini mengindikasikan bahwa anggota masyarakat di sekitar Hutan Larangan
Adat Rumbio telah memiliki pendidikan yang beragam namun masih didominasi tingkat menengah dan sedang.

Hutan Larangan Adat Rumbio dikelola oleh dua suku yaitu domo dan putopang, hal ini sesuai dengan data responden bahwa suku yang paling banyak adalah domo dan putopang sebanyak masing-masing 16 orang $(21,33 \%)$ sehingga keseluruhan dari reponden dari suku tersebut adalah 32 orang $(42,66 \%)$. Suku yang lain juga beragam yang tinggal di wilayah sekitar Hutan Larangan Adat Rumbio dimana terdapat 12 suku.

Responden paling banyak memiliki pendapatan < 2000.000 yaitu $56 \%$ atau 52 orang dimana $10 \%$ responden hanya memperoleh penghasilan kurang dari $\mathrm{Rp} 1000.000$ sedangkan yang memiliki pendapatan sedang yaitu antara Rp 2000.001 RpRp 4000.000 sebanyak 16 orang $(31,34 \% \%)$. Masyarakat yang miliki pendapatan tinggi atau > Rp 4000.000 adalah sebanyak 9 orang (12\%). Dengan memiliki pendapatan yang lebih tinggi akan mempengaruhi kualitas hidup dan diharapkan memiliki kepedulian terhadap lingkungan. Adapun jika mengacu kepada UMR (Upah Minimum Regional) Kabupaten 
Kampar tahun 2016 yaitu Rp 2.095.000 maka masih banyak masyarakat yang memiliki tingkat pendapatan dibawah UMR sehingga upaya pemberian insentif dari lingkungan merupakan salah satu upaya yang dapat dilakukan untuk peningkatan kesejahteraan.

\section{Partisipasi Masyarakat}

Pengelolaan Hutan Larangan Adat Rumbio dengan melibatkan lembaga adat Kenagarian Rumbio dan setiap desa yang ada disekitar Hutan Larangan Adat Rumbio. Untuk mengetahui tingkat partisipasi masyarakat terhadap kelestarian dan kegiatan pengelolaan jasa lingkungan di Hutan Larangan Adat Rumbio disajikan pada Tabel 3.

\begin{tabular}{cccc}
\multicolumn{4}{c}{ Tabel 3. Tingkat Partisipasi } \\
\multicolumn{4}{c}{ Masyarakat } \\
\hline No & $\begin{array}{c}\text { Tingkat } \\
\text { partisipasi }\end{array}$ & Jumlah & Persentase \\
\hline 1 & Tinggi & 20 & 26,66 \\
2 & Sedang & 44 & 58,66 \\
3 & Rendah & 11 & 14,66 \\
& Total & 75 & 100 \\
\hline
\end{tabular}

\section{Berdasarkan Tabel 3 dapat} partisipasi masyarakat paling besar pada tingkat sedang dimana masyarakat selalu siap untuk ikut berpartisipasi dalam kegiatan pelestarian hutan adat Hutan Larangan Adat Kenegerian
Rumbio dikelola oleh masyarakat secara swadaya dibawah Kelembagaan Adat Kenegerian Rumbio. Masyarakat yang memiliki partisipasi rendah bukan berarti tidak ikut serta dalam pelestarian hutan tapi sebagian masyarakat mendukung secara tidak langsung dan masih bersifat pasif. Untuk masyarakat dengan tingkat partisipasi tinggi memiliki peran lebih besar dengan ikut melakukan berbagai kegiatan dalam pelestarian Hutan Larangan Adat Rumbio dan membentuk lembaga swadaya masyakat peduli hutan termasuk menjalin kerjasama dengan instansi pemerintah dan swasta untuk mendukung upaya pelestarian hutan dengan bentuk kegiatan yang telah dilakukan seperti penghijauan, pelabelan pohon, pengayaan jenis dan lain-lain. Hal ini sesuai dengan kategori International Institute of Rural Reconstruction [IIRR],1998 yang menggambarkan tingkat kelembagaan partisipasi yaitu tingkat partisipasi pasif karena masyarakat telah menyerahkan pengelolaannya kepada tokoh adat dan desa sehingga kegiatan yang dilakukan secara proaktif masih kurang. Pihak pemerintahan desa juga secara aktif mendukung kegiatan pengelolaan hutan 
larangan adat dengan berkoordinasi dengan lembaga adat.

Masyarakat adat Kenegerian Rumbio mampu bekerja secara efektif untuk mengatur dan mengelola hutan larangan adat yang dapat mempertahankan keberadaan dan kelestariannya. Unsur-unsur modal sosial seperti nilai-nilai adat, norma, kepercayaan dan partisipasi masyarakat mampu membentuk suatu ikatan di dalam masyarakat untuk bekerjasama secara proaktif dalam mempertahankan tradisi dan kebesaran adat Kenegerian Rumbio (Rijal, 2013). Masyarakat Adat Kenegerian Rumbio mampu mempertahankan kelestarian Hutan Larangan Adat seluas $530 \mathrm{Ha}$ walaupun secara fungsi baik berdasarkan Tata Guna Hutan Kesepakatan (TGHK) maupun berdasarkan Rencana Tata Ruang Wilayah Provinsi Riau (RTRWP) berada di luar Kawasan Hutan (Non Kawasan Hutan).

\section{Faktor-Faktor yang Mempengaruhi}

\section{Partisipasi Masyarakat}

Hubungan antara tingkat partisipasi responden (Y) dengan beberapa faktor yang mempengaruhi secara sekaligus yaitu umur $\left(X_{1}\right)$, pendidikan responden (X2),
Pengetahuan $\left(X_{3}\right)$, pendapatan $\left(X_{4}\right)$, tingkat ketergantungan pada hutan $\left(X_{5}\right)$, kelembagaan adat $\left(\mathrm{X}_{6}\right)$ dan dukungan pemerintah $\left(X_{7}\right)$ diperoleh persamaan regresi sebagai berikut:

$$
\begin{aligned}
Y= & 4,59-0,068 X_{1}+\mathbf{0 , 4 2 9} \mathbf{X}_{2}+\mathbf{0 , 3 6 2} \mathbf{X}_{3} \\
& +0,084 X_{4}+\mathbf{0 , 5 5 9} \mathrm{X}_{5}+\mathbf{1 , 2 8} \mathrm{X}_{6}- \\
& 0,199 X_{7} \\
& (t=5,51) \quad(\mathrm{t}=-0,68) \quad(\mathrm{t}=\mathbf{3 , 1 8}) \quad(\mathrm{t}=\mathbf{3 , 7 8}) \\
& (\mathrm{t}=0,74) \quad(\mathrm{t}=\mathbf{2 , 6 7}) \quad(\mathrm{t}=\mathbf{3 , 1 6}) \quad(\mathrm{t}=-1,81) \\
& \left(\mathrm{R}^{2}=54,9\right) \quad(\mathrm{F}=4,28)
\end{aligned}
$$

Partisipasi secara signifikan dipengaruhi oleh ketujuh variabel yang diuji. Secara bersama-sama ketujuh variabel tersebut dapat menerangkan naik-turunnya partisipasi sebesar 54,9 persen. Hal ini dapat dijelaskan karena faktor eksternalitas yang tidak terdefinisi di dalam model ini sangat besar pengaruhnya terhadap partisipasi responden. Di dalam pengujian ini model hanya melibatkan variabel sosial ekonomi. Diluar variabel-variabel tersebut tidak tercakup di dalam pengujian model ini.

Hasil uji parsial menunjukkan bahwa variabel pendidikan (X2), pengetahuan $\left(\mathrm{X}_{3}\right)$, tingkat ketergantungan pada hutan $\left(\mathrm{X}_{5}\right)$ dan kelembagaan adat (X6) memiliki pengaruh signifikan terhadap partisipasi responden. Hasil uji statistik tersebut dapat ditafsirkan, empat faktor yang 
memiliki pengaruh nyata terhadap partisipasi dalam pelestarian hutan adalah pendidikan, pengetahuan, tingkat ketergantungan pada hutan dan kelembagaan adat.

Pendidikan merupakan salah satu kriteria untuk menentukan kualitas sumberdaya manusia. Pada penelitian ini pendidikan dan pengetahuan responden berpengaruh signifikan kepada tingkat partisipasinya. Dengan memiliki pendidikan dan pengetahuan yang baik maka dapat meningkatkan partisipasi responden. Selain itu tingkat pendidikan yang lebih tinggi berpengaruh sangat baik untuk tingkat pengetahuan sesuai dengan penelitian Rusdianti (2012).

\section{Tingkat}

ketergantungan responden terhadap hutan berrbanding lurus dengan partisipasi responden. Semakin tinggi ketergantungan pada hutan maka partisipasi dalam menjaga kelestarian semakin baik. Dalam kelembagaan adat ninik mamak Kampar, masing-masing ninik mamak dari berbagai tingkatan bawah sampai ke atas, memiliki independensi dalam menyelesaikan masalah internal, namun apabila tidak dapat diputuskan, ninik mamak dapat meminta pertimbangan kelembagaan ninik mamak yang lebih tinggi diatasnya sedangkan ninik mamak diatasnya tidak boleh mencampuri urusan ninik mamak dibawahnya, apabila tidak diminta.

Lembaga adat yang berperan alam pelestarian dan pengelolaan hutan memberikan pengaruh signifikan terhadap pelestarian dan pengelolaan hutan. Hutan Larangan Adat Rumbio diatur melalui ketentuan hukum adat yang ditetapkan dalam musyawarah adat Kenagarian. Dalam struktur kelembagaan adat di Rumbio, pucuk pimpinan adat terdiri dari 10 penghulu/andiko dari perwakilan empat suku (Domo, Putopang, Piliang, Chaniago dan Kampai). Untuk pembagian peran pengelolan kawasan Hutan Larangan Adat, kelembagaan adat yang bertanggung jawab dan berwenang mengurusi kelembagaan ninik mamak dari dua persukuan yaitu Datuk Godang dan Datuk Ulak Sumano sebagai pucuk adat dari suku masingmasing. Tidak ada batas wilayah yang jelas diantara pengelolaan dua pucuk persukuan tersebut. Dalam struktur adat yang seharusnya bertugas sebagai fungsi pengawasan dan keamanan adalah dubalang, namun dalam pelaksanaannya biasanya ditunjuk orang-orang kepercayaan ninik mamak 
dari suku masing-masing yang memiliki akses keseharian ke hutan atau tempat tinggalnya dekat dengan Hutan Larangan Adat Rumbio.

Lembaga adat yang ada di Kenagarian Rumbio di Dukungan masyarakat terhadap kelestarian hutan adat dilakukan dengan melalui lembaga adat yang secara swadaya menjaga areal ini. Selain itu upaya kelestarian juga didukung oleh pihak pemerintah daerah melalui Dinas kehutanan dan Badan Lingkungan Hidup Kabupaten Kampar demikian juga dengan pemerintah provinsi dan nasional.

Pilihan Insentif Kegiatan Pengelolaan Jasa Lingkungan dan Masyarakat Desa Sekitar Hutan Adat Rumbio

Pemberian insentif merupakan pengakuan dan reward yang dapat mengurangi tekanan terhadap hutan yang dekonstruktif. Nurfatriani (2008) bahwa untuk mengimplementasikan pembayaran jasa lingkungan ditingkat tapak (site), perlu dipahami terlebih dahulu definisi dari jasa lingkungan, pembayaran jasa lingkungan, produk, mekanisme dan tujuan dari pembayaran jasa lingkungan, serta siapa user dan provider. Hal itu dibutuhkan untuk menyamakan persepsi antara stakeholder yang terlibat sehinggga dapat meminimalkan perbedaan persepsi dalam perumusan regulasi dan pelaksanaannya di lapangan.

Pilihan insentif untuk kegiatan pengelolaan jasa lingkungan berupa air dan perdagangan karbon yang telah terpilih melalui diskusi dengan pihak desa serta instansi terkait, akan menjaga dan mengembangkan program insentif. Diantara pilihan insentif, diperoleh tujuh pilihan yang dipilih dengan pertimbangan berdasarkan kelayakan dan kecocokan dalam konteks masyarakat desa sekitar Hutan Larangan Adat Rumbio.

Pemilihan tujuh pilihan insentif adalah 1) 'penyediaan lapangan kerja yang terkait dengan kegiatan pengelolaan jasa lingkungan', 2) 'penyediaan subsidi', 3) 'pengenalan praktek konservasi', 4) 'pipanisasi untuk mengalirkan air dari mata air', 5) 'penyediaan generator listrik, 6) 'penyediaan barang untuk pertanian dan perikanan', dan 7) pembuatan dan pengelolaan hutan adat.

\section{Preferensi Masyarakat Desa sekitar Hutan Adat Rumbio pada Pilihan Insentif}

Untuk memastikan bahwa masyarakat ikut berpartisipasi dalam kegiatan pengelolaan jasa lingkungan 
dan untuk meningkatkan efektivitas, skema dalam kegiatan tersebut perlu disesuaikan dalam pilihan insentif masyarakat untuk memenuhi preferensi dari masyarakat desa yang ada disajikan pada Gambar 1. Persentase pada Gambar 1 merupakan nilai ratarata perbandingan berpasangan antara pilihan 2 pilihan insentif dimana total persentase adalah 100\% kemudian dibandingkan secara berpasangan dengan setiap pilihan 6 insentif lainnya. Hasil setiap perbandingan ini dirataratakan sehingga diperoleh nilai perbandingan keseluruhan dari pilihan pada ke 7 pilihan insentif yang ada.

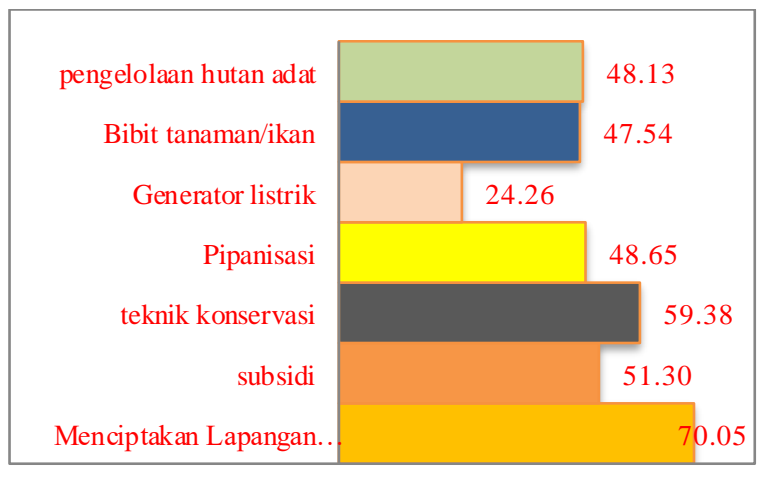

Gambar

1. Preferensi Piihan Responden Masyarakat Desa di Sekitar Hutan Adat Rumbio Sesuai Pilihan Insentif

Preferensi responden terhadap 7 pilihan alternatif bentuk insentif adalah sebagai berikut, penciptaan lapangan kerja adalah pilihan yang paling diminati (70,05\%), sedangkan 59,38\% responden memilih perbaikan teknik konservasi, penyediaan subsidi berkisar $51,30 \%$, penyediaan pipanisasi untuk air minum isi ulang sebesar $48,65 \%$, pengelolaan hutan adat yang terkait dengan kegiatan pengelolaan jasa lingkungan dipilih 48,13\% responden, $47,54 \%$ responden memilih penyedian bibit tanaman atau ikan, dan 24,26\% menyetujui jika diberikan bantuan generator listrik sebagai program insentif.

Lapangan pekerjaan yang di lokasi penelitian didominasi oleh sektor pertanian yaitu kebun karet dan perikanan tambak sebesar $72 \%$ dari total responden. Terbatasnya jenis pekerjaan menyebabkan kurangnya peluang untuk meningkatkan pendapatan sehingga dengan terbukanya peluang penciptaan lapangan kerja dapat mengurangi tekanan terhadap hutan. Adanya usaha penjualan air yang bersumber dari hutan adat dapat menjadi salah satu alternatif lapangan pekerjaan. Penyediaan subsidi untuk masyarakat yang mata pencaharian tergantung dengan hutan adat Rumbio adalah dengan cara memberikan pekerjaan sebagai penjaga pengamanan hutan atau membantu modal untuk usaha sehingga tidak tergantung lagi kepada hutan adat 
Rumbio.

Praktek konservasi dimaksudkan sebagai teknik agroforestri yang bersifat melindungi lahan-lahan yang selama ini dikelola masyarakat di sekitar Hutan Larangan Adat Rumbio agar tetap terjaga kesuburan tanah dan keberadaan unsur hara yang terkandung didalamnya. Pembuatan dan pengelolaan hutan adat dimaksudkan upaya merehabilitasi areal di kawasan hutan adat Rumbio yang terganggu akibat okupasi oleh sebagian anggota masyarakat yang dilakukan sebelumnya.

Penyediaan pipanisasi untuk air minum dengan mengalirkan air dari sumber air hutan adat ke rumah penduduk karena masyarakat harus mengambil air dengan menggunakan gerigen ke mata air dan hanya 1 (satu) dusun di Desa Padang Mutung yang

\begin{tabular}{|c|c|c|c|c|}
\hline \multirow{2}{*}{ Peringkat } & \multicolumn{4}{|c|}{ Nama Desa Sekitar Hutan Adat Rumbio } \\
\hline & Kototibun & Rumbio & Pulau Sarak & Padang Mutung \\
\hline 1 & $\begin{array}{l}\text { Menciptakan } \\
\text { Lapangan } \\
\text { pekerjaan } \\
(72,15 \%)\end{array}$ & $\begin{array}{l}\text { Menciptakan } \\
\text { Lapangan } \\
\text { Pekerjaan } \\
(62,74 \%)\end{array}$ & $\begin{array}{l}\text { Teknik } \\
\text { konservasi } \\
(85,14 \%)\end{array}$ & $\begin{array}{l}\text { Menciptakan } \\
\text { Lapangan } \\
\text { pekerjaan } \\
(67,64 \%)\end{array}$ \\
\hline 2 & $\begin{array}{l}\text { Teknik } \\
\text { Konservasi } \\
(57,86 \%)\end{array}$ & $\begin{array}{l}\text { Teknik } \\
\text { Konservasi } \\
(58,56 \%)\end{array}$ & $\begin{array}{l}\text { Menciptakan } \\
\text { Lapangan } \\
\text { pekerjaan } \\
(71,43 \%)\end{array}$ & Subsidi $(58,21 \%)$ \\
\hline 3 & Subsidi $(54,20 \%)$ & $\begin{array}{l}\text { Lahan kelompok } \\
\text { tani }(58,21 \%)\end{array}$ & $\begin{array}{l}\text { Pipanisasi } \\
(51,43 \%)\end{array}$ & $\begin{array}{l}\text { Teknik Konservasi } \\
(54,11 \%)\end{array}$ \\
\hline
\end{tabular}

telah membuat pipanisasi. Secara umum masyarakat telah dialiri listrik dari PLN sehingga penyediaan genset menjadi pilihan insentif paling rendah yang diinginkan oleh reponden.

Responden dari Desa Koto Tibun, Desa Rumbio dan Desa Padang Mutung paling banyak memilih penciptaan lapangan kerja. Sementara responden dari Desa Pulau Sarak memilih pemberian teknik konservasi sebagai pilihan insentif yang paling banyak diminati. Pemilihan teknik konservasi dan pemberian subsidi dipilih oleh responden dari 4 desa sebagai pilihan menengah. Pemberian generator listrik menempati peringkat terendah di semua desa. Preferensi dari ke tujuh pilihan insentif dari setiap desa disajikan pada Tabel 7.

\section{Tabel 7. Preferensi Pilihan Insentif disetiap Desa sekitar Hutan Adat Rumbio}

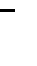




\begin{tabular}{|c|c|c|c|c|}
\hline \multirow{2}{*}{ Peringkat } & \multicolumn{4}{|c|}{ Nama Desa Sekitar Hutan Adat Rumbio } \\
\hline & Kototibun & Rumbio & Pulau Sarak & Padang Mutung \\
\hline 4 & $\begin{array}{l}\text { Pipanisasi } \\
(52,03 \%)\end{array}$ & $\begin{array}{l}\text { Pipanisasi } \\
(57,44 \%)\end{array}$ & $\begin{array}{l}\text { Bibit } \\
\text { tanaman/ikan } \\
(49.52 \%)\end{array}$ & $\begin{array}{l}\text { Pipanisasi } \\
(50,30 \%)\end{array}$ \\
\hline 5 & $\begin{array}{l}\text { Lahan kelompok } \\
\text { tani }(47,79 \%)\end{array}$ & $\begin{array}{l}\text { Bibit } \\
\text { tanaman/ikan } \\
(49,66 \%)\end{array}$ & $\begin{array}{l}\text { Lahan } \\
\text { kelompok tani } \\
(43.81 \%)\end{array}$ & $\begin{array}{l}\text { Bibit tanaman / } \\
\text { ikan (49,22\%) }\end{array}$ \\
\hline 6 & $\begin{array}{l}\text { Bibit } \\
\text { tanaman/ikan } \\
(44,79 \%)\end{array}$ & Subsidi $(41,28 \%)$ & $\begin{array}{l}\text { Subsidi } \\
(39.05 \%)\end{array}$ & $\begin{array}{l}\text { Lahan kelompok } \\
\text { tani }(44,32 \%)\end{array}$ \\
\hline 7 & $\begin{array}{l}\text { Generator listrik } \\
(26,73 \%)\end{array}$ & $\begin{array}{l}\text { Generator listrik } \\
(23,68 \%)\end{array}$ & $\begin{array}{l}\text { Generator } \\
\text { listrik }(7.62 \%)\end{array}$ & $\begin{array}{l}\text { Generator Listrik } \\
(26,34 \%)\end{array}$ \\
\hline
\end{tabular}

\section{Sumber : Data Primer Diolah, 2016}

Pada Tabel 7 diperoleh hasil dari setiap preferensi responden per desa yang merupakan hasil dari nilai ratarata perbandingan berpasangan antara pilihan 2 pilihan insentif berpasangan. Pilihan insentif tersebut kemudian yang dibandingkan secara berpasangan dengan setiap pilihan 6 insentif lainnya kemudian hasil setiap perbandingan ini dirata-ratakan sehingga diperoleh nilai perbandingan keseluruhan dari pilihan pada ke 7 pilihan insentif yang ada. Untuk peringkat dari ke 7 insentif dibuat sesuai hasil perhitungan yang diperoleh dengan mengurutkan dari nilai persentase yang tertinggi pada setiap desa.

\section{Kepentingan Relatif dari Pilihan Insentif untuk Mata Pencaharian Masyarakat Desa Sekitar Hutan Adat Rumbio yang Berkelanjutan}

Kegiatan pengelolaan jasa lingkungan dapat mendorong masyarakat setempat dengan berbagai alternatif mata pencaharian hingga pemberian kompensasi akibat hilangnya mata pencaharian berbasis hutan ketika kawasan hutan tersebut harus dilindungi untuk keperluan hasil jasa lingkungannya. Tetapi kegiatan ini juga dapat mencegah masyarakat setempat dengan tidak mengikutsertakan mereka dari kegiatanpengelolaan jasa lingkungan yang berakibat hilangnya pendapatan masyarakat desa tersebut.

Dalam rangka melihat hubungan penting terhadap pilihan insentif untuk penghidupan masyarakat desa yang 
berkelanjutan, digunakan metode Analytic HierarchyProcess (AHP) dan metode Sustainable Livelihoods Approach (SLA). SLA adalah konsep kesejahteraan, meliputi aspek ekonomi dan non ekonomi, awalnya dikembangkan oleh Chambers dan Conway (1992) dan diperkenalkan oleh DepartementFor International Development (DFID) Inggris. SLA telah digunakan baik untuk desain proyek dan memantau serta mengevaluasi dampak. SLA menganalisa strategi mata pencaharian masyarakat yang dibangun di atas 5 aspek utama yang berbeda (ekonomi, sosial, sumberdaya alam, sarana fisik, dan sumberdaya manusia).

\section{Model Analisa Proses Hirarki dengan SLA}

Metodologi AHP dikembangkan oleh Thomas Saaty pada tahun 1970an. Metodologi AHP merupakan teknik memperoleh penerimaan yang luas dalam beberapa ilmu, terutama ketika melibatkan peringkat dari alternatif keputusan dalam memutuskan masalah. Melalui trade-offs (pertukaran), menunjukkan keuntungan dan kerugian dari berbagai pihan dalam kondisi yang tidak pasti.

Pada penelitian ini, pentingnya hubungan dari 5 aspek utama dari penghidupan yang berkelanjutan telah terukur dan pentingnya pilihan insentif dibandingkan dengan perspektif dari 5 aset. Pentingnya hubungan dari pilihan insentif untuk penghidupan masyarakat setempat secara berkelanjutan telah diukur disajikan pada Gambar 2.

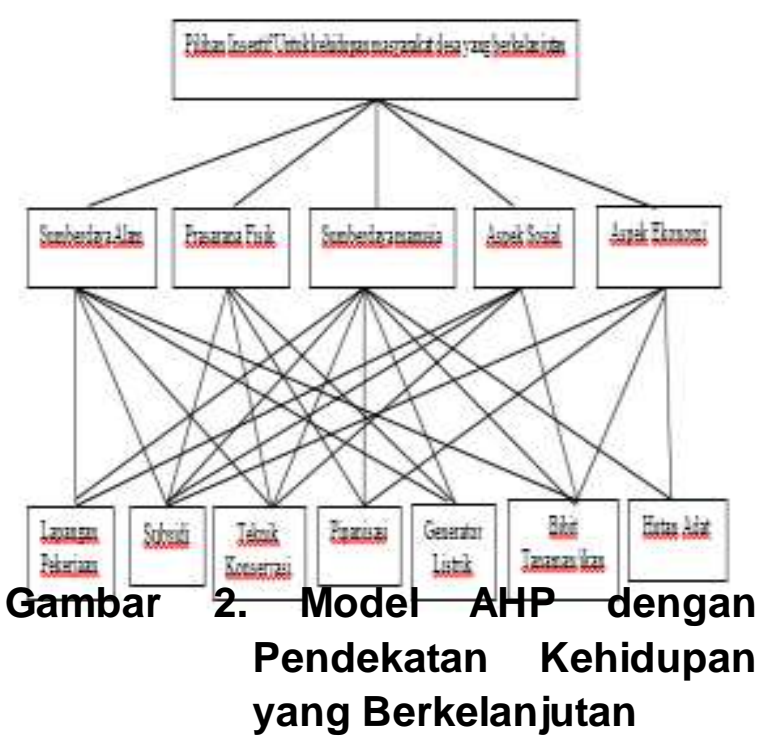

Hasil dan Analisa

Diantara faktor-faktor yang berpengaruh dalam Analisis Hirarchy Process (faktor Sumberdaya alam, faktor prasarana fisik, faktor sumberdaya manusia, saktor sosial, faktor ekonomi). Hubungan antar faktor dengan kepentingan kehidupan masyarakat disajikan pada Tabel 8 . 
Tabel 8. Pentingnya Hubungan Antara Faktor Yang ada Dengan Kehidupan Masyarakat Desa

\begin{tabular}{|c|c|c|c|c|c|c|}
\hline Faktor & SDA & Sarana & SDM & Sosial & Ekonomi & Kepentingan \\
\hline SDA & 100 & 7,20 & 1,10 & 1,10 & 1,00 & $11,40(2)$ \\
\hline Sarana & 0,14 & 100 & 0,14 & 0,15 & 0,14 & $1,57(5)$ \\
\hline SDM & 0,91 & 6,90 & 10 & 1,20 & 0,77 & $10,78(3)$ \\
\hline Sosial & 0,91 & 6,80 & 0,83 & 10 & 1,20 & $10,74(4)$ \\
\hline Ekonomi & 1,00 & 7,30 & 1,30 & 0,83 & 100 & $11,43(1)$ \\
\hline
\end{tabular}

\section{Sumber: Data Primer Diolah, 2016}

Diantara faktor-faktor yang menjadi kriteria dalam pemilihan insentif bagi masyarakat di 4 desa di sekitar Hutan Larangan Adat Rumbio seperti sumberdaya alam, prasarana fisik, sumberdaya manusia, kondisi sosial masyarakat dan kondisi ekonomi masyarakat desa, maka dapat yaitu 1,57.

Tabel 9. Kepentingan dari Masing-Masing Asset untuk Mata Pencaharian Masyarakat Desa yang Berkelanjutan

\begin{tabular}{|l|c|c|c|c|c|c|c|c|}
\hline \multicolumn{1}{|c|}{ Faktor } & Bobot & Kerja & Subsidi & Konservasi & Pipa & Genset & Bibit & Lahan \\
\hline SDA & 0,2482 & 0,2457 & 0,2232 & 0,2010 & 0,1382 & 0,1107 & 0,0569 & 0,0244 \\
\hline Sarana & 0,0338 & 0,3331 & 0,1693 & 0,1522 & 0,1286 & 0,0687 & 0,0727 & 0,0754 \\
\hline SDM & 0,2309 & 0,2124 & 0,2068 & 0,1848 & 0,1786 & 0,0811 & 0,0706 & 0,0656 \\
\hline Sosial & 0,2334 & 0,2446 & 0,1909 & 0,1544 & 0,1787 & 0,0949 & 0,0724 & 0,0640 \\
\hline Ekonomi & 0,2456 & 0,2578 & 0,1958 & 0,2252 & 0,1137 & 0,0923 & 0,0646 & 0,0506 \\
\hline \multicolumn{2}{|c|}{ Peringkat } & $\mathbf{0 , 2 4 1 7}$ & $\mathbf{0 , 2 0 1 5}$ & $\mathbf{0 , 1 8 9 0}$ & 0,1495 & 0,0933 & 0,0657 & 0,0511 \\
\cline { 2 - 9 } & $\mathbf{1}$ & $\mathbf{2}$ & $\mathbf{3}$ & $\mathbf{4}$ & $\mathbf{5}$ & $\mathbf{6}$ & $\mathbf{7}$ \\
\hline
\end{tabular}

\section{Sumber: Data Primer Diolah, 2016}

Berdasarkan Tabel 9 tingkat kepentingan dari tujuh pilihan untuk mata pencaharian masyarakat desa sekitar Hutan Adat Rumbio yang berkelanjutan

disimpulkan bahwa faktor ekonomi adalah hal paling penting $(11,43)$. Kedua adalah faktor Sumberdaya Alam $(11,40)$, ketiga adalah faktor sumberdaya manusia $(10,78)$ dan keempat adalah faktor sosial $(10,74)$. Pentingnya faktor sarana fisik memperoleh skor terendah, 
teknik konservasi menempati peringkat ketiga $(18,90 \%)$. Pentingnya pemberian pipanisasi, generator listrik, pemberian bibit tanaman/ikan dan pembangunan hutan adat masing-masing memperoleh $14,95 \%, \quad 9,33 \%, \quad 6,57 \%$ dan $5,11 \%$. Dengan merujuk pada prioritas pilihan insentif maka upaya yang dapat dilakukan adalah dengan memberikan peluang untuk memperoleh hak pemanfaatan mata air kepada masyarakat dan pengembangan hasil hutan non kayu seperti lebah madu dan buah-buahan serta kegiatan wisata dan pendidikan dengan melibatkan masyarakat sekitar hutan.

Berdasarkan pilihan insentif dari masyarakat sekitar Hutan Larangan Adat Rumbio bahwa lapangan kerja yang menjadi pilihan utama untuk peningkatan taraf hidup secara ekonomi yang diikuti dengan pemberian subsidi. Kesadaran untuk menjaga lingkungan sehingga mata air yang ada disekitar Hutan Larangan Adat Rumbio tetap terjaga sudah disadari oleh masyarakat dengan melakukan kegiatan konservasi tanah seperti penghijauan dan penambahan jenis pohon di hutan. Peningkatan taraf hidup secara ekonomi dengan penciptaan lapangan pekerjaan melalui hak/ijin untuk menjual sumberdaya air sehingga terbentuk beberapa usaha penampungan dan penjualan air oleh penduduk setempat.

Masyarakat yang telah ikut perperan aktif dalam menjaga kelestarian hutan adat dapat diberikan hak dalam pengelolaan jasa lingkungan. Pembayaran dan imbal jasa lingkungan diharapkan dapat menjadi suatu bentuk implementasi sistem insentif ekonomi berbasiskan pasar. Secara umum, pasar jasa lingkungan diartikan sebagai kesempatan bagi masyarakat yang hidup di dalam dan di sekitar kawasan konservasi untuk meningkatkan taraf hidupnya mereka tidak hanya dari segi ekonomi tetapi juga dari sisi lain yaitu dengan adanya peningkatan modal sosial dan pengakuan atas hak masyarakat dalam mengelola dan mengakses sumberdaya alam (ICRAF 2005 diacu dalam Nurfatriani 2008).

Hutan Larangan Adat Rumbio memiliki sumber mata air yang dimanfaatkan oleh masyarakat untuk keperluan sehari-hari masyarakat disekitar Hutan Larangan Adat Rumbio juga memanfaatkan air dari hutan adat Rumbio dengan melakukan usaha penjualan air. Usaha ini dilakukan oleh penduduk sekitar Hutan adat dengan 
membuat penampungan air yang dialirkan dengan pipa ke bak penampungan. Jumlah usaha penjualan air tersebar dibeberapa desa disekitar hutan sebayak 13 buah yang tersebar di Desa Pulau Sarak 8 buah, Desa Rumbio 2 buah dan Desa Koto Tibun 3 buah. Desa Pulau Sarak merupakan desa yang paling banyak mengusahakan kegiatan pengambilan air. Mata air yang berasal Hutan Larangan Adat Rumbio lebih dikenal dengan Mata Air Sikumbang menjadi usaha bagi masyarakat disekitar hutan.

Debit air pada penampungan yang ada di Desa Pulau Sarak sebanyak delapan penampungan memiliki 41 kran dengan total debit air 8,992 liter/detik. Pengelola menjual Air Sikumbang dengan satuan jerigen dengan kapasitas 30 liter kepada distributor. Setiap hari rata-rata jumlah air yang diambil sekitar 3.450 gerigen (Insusanty dan Ratnaningsih, 2014). Harga air di Pulau Sarak untuk setiap gerigen 30 liter adalah Rp. 700,-. Biasanya para distributor membeli air dengan jumlah yang cukup banyak dengan menggunakan mobil niaga dan becak.

Hasil kesepakatan pihak Desa Pulau Sarak dengan pengusaha air yaitu setiap pemilik perusahaan dan pemilik mobil distribusi diwajibkan memberikan retribusi ke desa dalam pembangunan jalan dan infratruktur lainnya. luran untuk desa dari pemilik perusahaan air yaitu Rp100.000,00 - Rp 200.00,00 per bulan, sedangkan dari semua mobil yang keluar masuk desa diperoleh pemasukan sebesar Rp 140.000 per hari. Pihak desa menggunakan pemasukan tersebut untuk keperluan pembangunan jalan, masjid, pendidikan, pembayaran guru honorer dan lainnya.

\section{KESIMPULAN DAN SARAN}

\section{Kesimpulan}

1. Faktor umur, pendidikan, pengetahuan, pendapatan, tingkat ketergantungan terhadap hutan, kelembagaan adat dan dukungan pemerintah memberikan pengaruh nyata secara bersama-sama terhadap partisipasi responden dalam pelestarian dan pengelolaan hutan. Secara parsial faktor - faktor yang mempengaruhi tingkat partisipasi responden secara signifikan adalah pendidikan, pengetahuan, tingkat ketergantungan terhadap hutan dan kelembagaan adat.

2. Berdasarkan dari hasil AHP untuk mengetahui preferensi masyarakat terhadap insentif yang dapat 
diberikan adalah penciptaan lapangan kerja $(24,17 \%)$ diperingkat pertama, pemberian subsidi menempati peringkat kedua (20.15\%), sedangkan perbaikan teknik konservasi menempati peringkat ketiga (18,90\%). Selanjutnya untuk pemberian pipanisasi, generator listrik, pemberian bibit tanaman/ikan dan pembangunan hutan adat masingmasing memperoleh 14,95\%, 9,33\%, $6,57 \%$ dan $5,11 \%$.

3. Pemberian insentif diarahkan pada pembayaran jasa lingkungan, yaitu kepada masyarakat adat sekitar hutan yang berkontribusi terhadap kelestarian hutan, sehingga dapat membantu keberlangsungan pemanfaatan sumber daya alam di Hutan Larangan adat dengan memberikan hak dalam pengelolaan jasa lingkungan berupa pemanfaatan air, pengembangan hasil hutan non kayu, dan kegiatan wisata dan pendidikan dengat melibatkan masyarakat.

\section{Saran}

1. Pengembangan program insentif yang efektif untuk pelestarian Hutan Larangan Adat Rumbio perlu disesuai preferensi masyarakat dengan pilihan insentif yang diinginkan yang dipengaruhi faktor umur, pendidikan, pengetahuan, pendapatan, tingkat ketergantungan masyarakat lembaga adat dan dukungan pemerintah.

2. Upaya dalam pengembangan dalam pengelolaan jasa lingkungan baik untuk pemanfaatan air kemasan dan pemasarannya, usaha hasil hutan non kayu seperti pengembangan lebah madu dan pengayaan dengan menanam pohon buah-buahan diareal Hutan Larangan Adat Rumbio serta pengembangan wisata dan pendidikan

\section{DAFTAR PUSTAKA}

Chambers,

$\mathrm{R}$. and Conway,G.R.(1992)'Sustainable Rural Livelihoods: Practical Concepts for the 21st Century', Discussion Paper 296. Brighton, UK: Institute of Development Studies

DFID (1999, 2000, 2001) Sustainable Livelihoods Guidance Sheets, Numbers1-8, London: Department for International Development (also available on www.livelihoods.org)

Ekayani M, Nuva, Yasmin R, Sinaga F, Maaruf LOM. 2014a. Wisata Alam Taman Nasional Gunung Halimun Salak: Solusi Kepentingan Ekologi dan Ekonomi. Jurnal IImu Pertanian Indonesia 19(1): 29-37 
Ekayani M, Nuva, Yasmin R, Saffitri LR, Bahroin I. 2014b. Taman Nasional Untuk Siapa? Tantangan Membangun wisata Alam Berbasis Masyarakat di Taman Nasional Gunung Halimun Salak. Jurnal Kebijakan Pertanian dan Lingkungan. 1(1): 46-52.

Idrus. S, Ahyar Ismail, Meti Ekayani. 2016. Potensi Pembayaran Jasa Lingkungan Hutan Mangrove di Kecamatan Jailolo Kabupaten Halmahera Barat. Jurnal IImu Pertanian Indonesia. 21 (3): 195202

Insusanty.E dan Ratnaningsih, 2014.Model Pengelolaan Jasa Lingkungan Di Hutan Adat Rumbio Kabupaten Kampar, Riau Tahun I. Laporan Hibah Bersaing

Insusanty.E dan Sadjati, 2015.Model Pengelolaan Jasa Lingkungan Di Hutan Adat Rumbio Kabupaten Kampar, Riau Tahun II. Laporan Hibah Bersaing

International Institute of Rural Reconstruction [IIRR]. 1998. Participatory Method in Community Based Coastal Resource Management. Volume I: Introductory Papers.

Nurfatriani, F. 2008. Merealisasikan Pembayaran Jasa Lingkungan: Belajar dari Pengalaman di Berbagai Lokasi. Info Sosial Ekonomi Kehutanan, No. 1 (8): 39-50.

Rijal, 2013. Peran Modal Sosial dalam Pelestarian Hutan (Studi Keberadaan Hutan Larangan Adat Kenegerian Rumbio di Desa Rumbio, Pulau Sarak, Padang
Mutung dan Koto Tibun Kecamatan Kampar Kabupaten Kampar) Tesis. Universitas Gadjah Mada.

Rusdianti, K. 2012. Konservasi lahan hutan mangrove serta upaya penduduk lokal dalam merehabilitasi ekosistem mangrove. Jurnal Sosiologi Pedesaan. 6(1): 1-17.

Saaty, T.L. 1989.Group decision making and the AHP. InThe Analytic Hierarchy Process (pp. 5967).Springer Berlin Heidelberg.

Vibrianto N, Ismail A, Ekayani M. 2015. Manfaat Ekonomi dan Daya dukung Kawasan Pantai Lombang Kabupaten Sumenep Provinsi Jawa Timur. Jurnal Risalah Kebijakan Pertanian dan Lingkungan. 2(2): 152-159.

Yitnosumarto, S. 2000. Dasar-dasar Statistika. Buku. PT Raja Grafindo Persada. Jakarta. 6p. 